\title{
Synthesis and Assessment of Antibacterial Activities of Ruthenium(III) Mixed Ligand Complexes Containing 1,10-Phenanthroline and Guanide
}

\author{
Atakilt Abebe and Tizazu Hailemariam \\ Science College, Bahir Dar University, Bahir Dar, Ethiopia \\ Correspondence should be addressed to Atakilt Abebe; atakiltabebe1@gmail.com
}

Received 23 July 2016; Accepted 29 September 2016

Academic Editor: Elena R. Milaeva

Copyright (C) 2016 A. Abebe and T. Hailemariam. This is an open access article distributed under the Creative Commons Attribution License, which permits unrestricted use, distribution, and reproduction in any medium, provided the original work is properly cited.

\begin{abstract}
In this work, two complexes of ruthenium(III) ([Ru(phen) $\left.{ }_{2} \mathrm{Cl}_{2}\right] \mathrm{Cl} \cdot 2 \mathrm{H}_{2} \mathrm{O}$ and $\left[\mathrm{Ru}(\mathrm{phen})_{2}(\mathrm{G}) \mathrm{Cl}\right] 2 \mathrm{Cl} \cdot \mathrm{H}_{2} \mathrm{O}$ ) were synthesized from 1,10-phenanthroline alone as well as from both 1,10-phenanthroline and guanide. The synthesis was checked using halide test, conductance measurement, and spectroscopic (ICP-OES, FTIR, and UV/Vis) analysis. Their in vitro antibacterial activities were also investigated on two Gram-positive (Staphylococcus aureus (S. aureus) and methicillin resistant Staphylococcus aureus (MRSA)) and two Gram-negative (Escherichia coli (E. coli) and Klebsiella pneumoniae (K. pneumoniae)) bacteria. These complexes showed wide-range better activities than the commercially available controls (Chloramphenicol and Ciprofloxacin) against even the most drug resistant $\mathrm{K}$. pneumoniae. [ $\left.\mathrm{Ru}(\mathrm{phen})_{2}(\mathrm{G}) \mathrm{Cl}\right] 2 \mathrm{Cl} \cdot \mathrm{H}_{2} \mathrm{O}$ inhibited S. aureus, MRSA, E. coli, and K. pneumoniae by $17.5 \%$, $27.4 \%, 16 \%$, and $52 \%$, respectively, better than Chloramphenicol. It also inhibited these pathogens by $5.9 \%, 5.1 \%, 2.3 \%$, and $17.2 \%$, respectively, better than Ciprofloxacin. Similarly, $\left[\mathrm{Ru}(\mathrm{Phen})_{2}(\mathrm{Cl})_{2}\right] \mathrm{Cl} \cdot 2 \mathrm{H}_{2} \mathrm{O}$ inhibited these pathogens by $11 \%, 8.7 \%, 0.1 \%$, and $31.2 \%$, respectively, better than Chloramphenicol. Therefore, after in vivo cytotoxicity investigations, these compounds can be considered as potential antibiotic drugs.
\end{abstract}

\section{Introduction}

Coordination chemistry is about tuning properties of metal ions using different ligands [1-3]. This includes stabilization of different oxidation states and modulation of the solvophilicity and electrophilic and nucleophilic properties of the metal ion [4-6]. While coordinating, the properties of the ligands themselves are also modified. For instance, the pharmacological activities and their crucial role in DNA/RNA base pairing through several hydrogen-bonding patterns of free oxypurines such as guanine can significantly change after complex formation $[7,8]$. Based on this, synthesis of different coordination compounds with desired properties by ligand tailoring has become a fascinating research field. Designing new coordination compounds with therapeutic abilities has been part of this activity [9-17]. From this perspective, there has been a growing interest in the chemistry community to examine the biological activities of ruthenium complexes $[18,19]$. Ruthenium $\left(5 s^{2} 4 d^{6}\right)$ frequently accesses +2 and +3 oxidation states at physiological conditions and can interact with nucleic acids, proteins, sulfur, or oxygen containing compounds and water in the cells [20-24]. Its interaction kinetics with the latter can be controlled using advantages of the unique properties of each kind of ligand. This enables the ligand exchange rates of ruthenium complexes to be close to those of cellular processes which make them suitable for therapeutic applications.

In this respect, numerous investigations in the properties and applications of ruthenium(II) complexes with 1,10-phenanthroline (phen) as a ligand or mixed with other ligands are reported [25-27]. Nevertheless, there is no report on the chemistry of ruthenium(III) complex containing 1,10-phenanthroline alone or 1,10-phenanthroline and guanide mixed.

The ideally placed nitrogen atoms along with their rigid planar structure and hydrophobic, electron-poor heteroaromatic, and $\pi$-acidic properties cooperatively made 1,10 -phenanthroline a classic chelating bidentate ligand. These properties enable it to have stacking interaction ability with DNA 
base pairs [28-31]. Guanine is a chemically inert oxypurine heteroaromatic molecule. Its inertness is changed by complex formation. The latter is favored in its guanide $\left(G^{-}\right)$form which is derived by deprotonation of guanine.

The purpose of this study is to examine the effects of 1,10 phenanthroline alone and mixed with guanide on the biological activity of $\mathrm{Ru}(\mathrm{III})$. The complex would orchestrate the binding ability of ruthenium with a range of biomolecules, the unique stacking interaction ability of 1,10-phenanthroline on cell genetic material, and the interaction of guanide through hydrogen bonding with cytosine residue of the genetic material.

\section{Experimental}

2.1. Chemicals. All chemicals used in the present work are as follows: 1,10-phenanthroline monohydrate (BDH Chemical Ltd., Poole, England), guanine (99\%, $\mathrm{ACROS}$ ), $\mathrm{RuCl}_{3}$, silver nitrate, sodium hydroxide, acetone, chloroform, sulfuric acid (Sigma Aldrich), methanol (Hi Media Laboratories Ltd., India), $\mathrm{KBr}$, dichloromethane, Mueller Hinton agar, and barium chloride (BLULUX Laboratories Ltd., India), and nitric acid (T.V. Industrial Estate, India).

2.2. Instruments and Methods. The electronic conductance was measured using $10^{-3} \mathrm{M}$ solution of each complex in deionized water with JENWAY 4200 conductivity meter at room temperature. The electronic spectra were recorded in the 200-800 nm region on Sanyo SP65 UV/Vis spectrophotometer. IR spectra were recorded using $\mathrm{KBr}$ discs in the $4000-400 \mathrm{~cm}^{-1}$ region on AVATAR 330 FTIR, Thermo Nicolet spectrophotometer. Ruthenium content was determined by PerkinElmer, Optima 7300 V HF Version ICP-OES spectrometer, digesting $10 \mathrm{mg}$ of each complex in concentrated nitric acid and diluting them using distilled water. Melting points were determined using STONE, STAFFORDSHIRE, ST15 OSA, UK, digital melting point apparatus. Chloride ions were determined thermogravimetrically using the $\mathrm{AgCl}$ precipitate obtained from the mixture of $10 \mathrm{~mL}$ solution of $1 \mathrm{mg}$ of each complex in distilled water with excess $\mathrm{AgNO}_{3}$ solution.

\subsection{Synthesis}

2.3.1. Synthesis of $\left[\mathrm{Ru}(\mathrm{Phen})_{2}(\mathrm{Cl})_{2}\right] \mathrm{Cl} \cdot 2 \mathrm{H}_{2} \mathrm{O}$. Ethanolic solution of 1,10-phenanthroline (1 $\mathrm{g}, 5 \mathrm{mmol})$ was added from a dropping funnel to an ethanolic solution of $\mathrm{RuCl}_{3}(0.5 \mathrm{~g}$, $2.5 \mathrm{mmol}$ ) being stirred magnetically in an ice bath. The mixture was allowed to stir for $3 \mathrm{~h}$ at room temperature. Reddish-brown homogeneous solution was obtained. The solvent was removed in vacuum. Reddish-brown powder was collected and washed three times with acetone to remove any unreacted 1,10-phenanthroline. It was recrystallized from ethanol to remove any unreacted $\mathrm{RuCl}_{3}$ (yield: $1.2 \mathrm{~g}, 80 \%$ ).

2.3.2. Synthesis of $\left[\mathrm{Ru}(\mathrm{Phen})_{2}(\mathrm{G})(\mathrm{Cl})\right] \mathrm{Cl} \cdot \mathrm{H}_{2} \mathrm{O}$. An aqueous solution of sodium guanide obtained from a reaction between guanine $(0.125 \mathrm{~g}, 8.0 \mathrm{mmol})$ and sodium hydroxide $(0.032 \mathrm{~g}$,
$8.0 \mathrm{mmol}$ ) was added from a dropping funnel to an aqueous solution of $\left[\mathrm{Ru}(\mathrm{Phen})_{2}(\mathrm{Cl})_{2}\right] \mathrm{Cl} \cdot 2 \mathrm{H}_{2} \mathrm{O}(0.5 \mathrm{~g}, 8.0 \mathrm{mmol})$ while stirring in an oil bath at $80^{\circ} \mathrm{C}$. The mixture was allowed to stir for $3 \mathrm{~h}$. The resulting orange-red homogeneous solution was mixed with $100 \mathrm{~mL}$ dichloromethane and stirred for $1 \mathrm{~h}$ and allowed to stand overnight. The organic (dichloromethane) phase was separated using separatory funnel. The dichloromethane was removed in vacuum and dark brown powder was collected and recrystallized from ethanol (yield: $0.546 \mathrm{~g}, 87 \%$ ). The reaction paths of the two synthetic complexes are shown in Scheme 1.

2.4. Antibacterial Activity Testing. The ligands and their metal complexes were evaluated for in vitro antibacterial activities against strains of two Gram-positive ( $S$. aureus (ATCC 25923) and methicillin resistant S. aureus (clinical isolate)) and two Gram-negative (E. coli (ATCC255922) and K. pneumoniae (ATCC986605)) bacteria. The bacterial strains were maintained in the appropriate blood agar base at $4^{\circ} \mathrm{C}$. Antibiotic discs (Ciprofloxacin $5 \mu \mathrm{g}$ and Chloramphenicol $30 \mu \mathrm{g}$ ) were used as reference. The minimum inhibitory concentration (MIC) against each bacterium was determined by preparing aqueous solutions of different concentrations of the complexes by serial dilution $(200 \mu \mathrm{g} / \mathrm{mL}, 300 \mu \mathrm{g} /$ $\mathrm{mL}, 400 \mu \mathrm{g} / \mathrm{mL}, 500 \mu \mathrm{g} / \mathrm{mL}, 600 \mu \mathrm{g} / \mathrm{mL}, 800 \mu \mathrm{g} / \mathrm{mL}$, and $1000 \mu \mathrm{g} / \mathrm{mL})$. The experiments were repeated three times to obtain consistent results. The antibacterial tests were carried out at the Amhara Regional Health Research Microbiology Laboratory Center, Bahir Dar, Ethiopia.

\section{Results and Discussion}

The analytical data of the complexes are indicated in Table 1.

3.1. Molar Conductance of the Metal Complexes. The conductance measurements, recorded for $10^{-3} \mathrm{M}$ solutions of the metal complexes in deionized water, are listed in Table 1. The data shows that both complexes are 1:1 electrolytes [32]. The lower conductance of $\left[\mathrm{Ru}(\text { phen })_{2}(\mathrm{G})(\mathrm{Cl})\right] \mathrm{Cl} \cdot \mathrm{H}_{2} \mathrm{O}$ compared to $\left[\mathrm{Ru}(\text { phen })_{2} \mathrm{Cl}_{2}\right] \mathrm{Cl} \cdot 2 \mathrm{H}_{2} \mathrm{O}$ is a consequence of increase in molar mass and the surface area. Hence the speed of mobility of the cation decreases as a result of the decrease in the kinetic energy imparted by the electric field from measurement instrument [33].

3.2. Electronic Spectra. The electronic spectra of the complexes are displayed in Figure 1 and Table 2.

The complexes exhibited simple characteristic $\mathrm{d}$ - $\mathrm{d}$ transitions. The difference in the band position for $\mathrm{d}$ - $\mathrm{d}$ transition absorption of $\mathrm{RuCl}_{3}$ and the complexes may be explained by assuming different environments around the metal ion following the coordination $[34,35]$. The coordination of $1,10-$ phenanthroline to $\mathrm{Ru}(\mathrm{III})$ results in a distorted octahedral geometry. Consequently, the $e_{\mathrm{g}}$ orbitals split to $\mathrm{d}_{z 2}$ and $\mathrm{d}_{x 2-y 2}$ resulting in two transitions $\left(\mathrm{t}_{2 \mathrm{~g}} \rightarrow e_{\mathrm{g}}\left(\mathrm{d}_{z 2}\right)\right.$ and $\left.\mathrm{t}_{2 \mathrm{~g}} \rightarrow e_{\mathrm{g}}\left(\mathrm{d}_{x 2-y_{2}}\right)\right)$. [Ru(Phen $\left.)_{2}(\mathrm{G})(\mathrm{Cl})\right] \mathrm{Cl} \cdot \mathrm{H}_{2} \mathrm{O}$ demonstrated absorption at longer wavelength (Figure 1(c)) than $\left[\mathrm{Ru}(\mathrm{Phen})_{2}(\mathrm{Cl})_{2}\right] \mathrm{Cl} \cdot 2 \mathrm{H}_{2} \mathrm{O}$ (Figure $1(\mathrm{~b})$ ). This is probably 
TABLE 1: Analytical data of the complexes.

\begin{tabular}{|c|c|c|c|c|c|}
\hline \multirow[t]{2}{*}{ Complex (color) } & \multirow[t]{2}{*}{ Melting point $/{ }^{\circ} \mathrm{C}$} & \multirow[t]{2}{*}{ Yield (\%) } & \multicolumn{2}{|c|}{$\begin{array}{l}\text { Elemental estimation } \\
\text { Calculated (found) (\%) }\end{array}$} & \multirow{2}{*}{$\begin{array}{l}\text { Molar conductivity } \\
\Lambda_{\mathrm{M}}\left(\mathrm{S} \mathrm{cm}^{2} \mathrm{~mol}^{-1}\right)\end{array}$} \\
\hline & & & $\mathrm{Ru}$ & $\mathrm{Cl}$ & \\
\hline$\left[\mathrm{Ru}(\text { phen })_{2}(\mathrm{Cl})_{2}\right] \mathrm{Cl} \cdot 2 \mathrm{H}_{2} \mathrm{O}$ (reddish brown) & $>300$ & 80 & $16.74(16.62)$ & $5.88(5.66)$ & 121.50 \\
\hline$\left[\mathrm{Ru}(\text { phen })_{2}(\mathrm{G})(\mathrm{Cl})\right] \mathrm{Cl} \cdot \mathrm{H}_{2} \mathrm{O}$ (orange red) & $>300$ & 87 & $14.47(14.23)$ & $5.07(4.89)$ & 87.26 \\
\hline
\end{tabular}

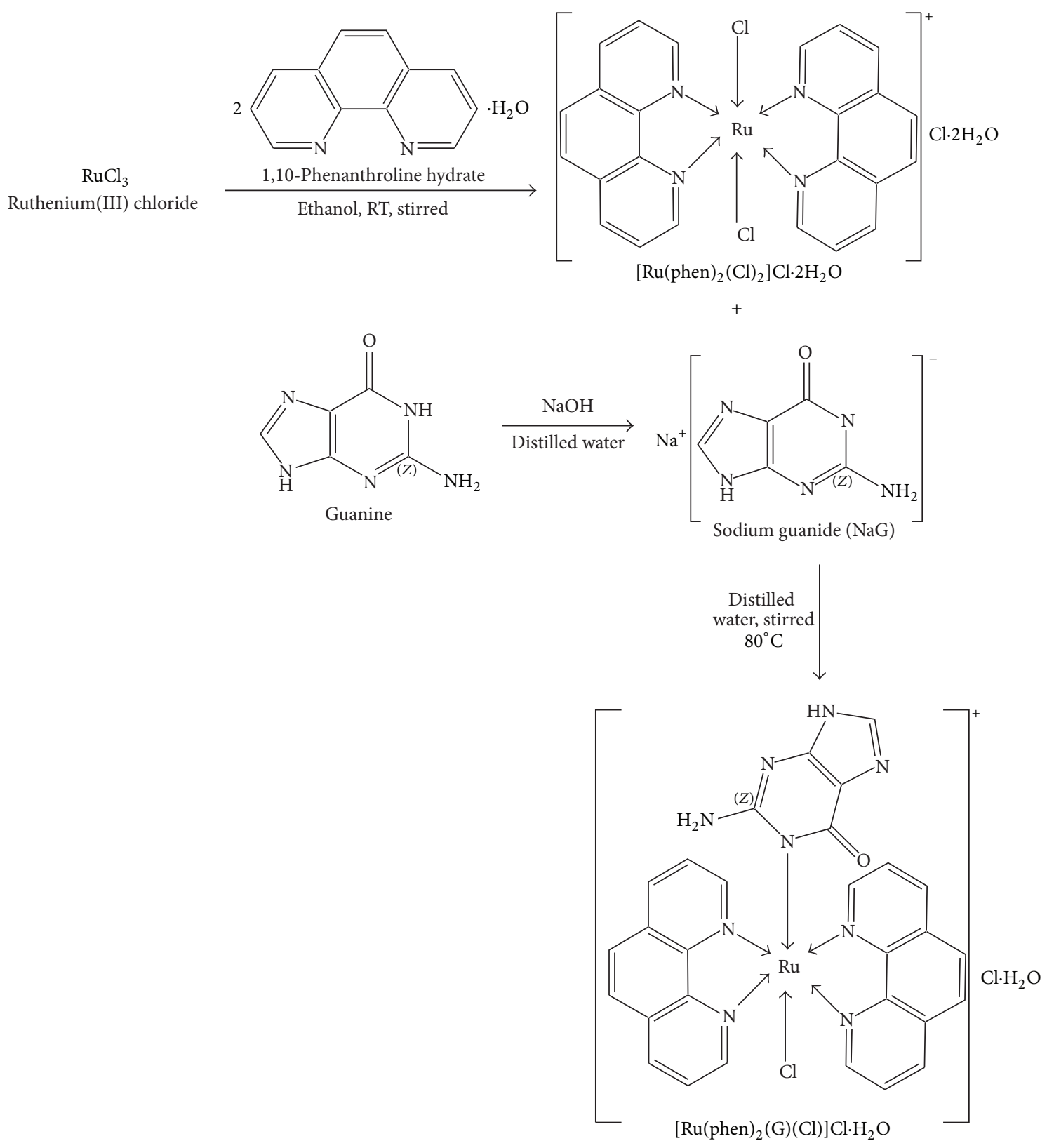

Scheme 1: Synthesis of $\left[\mathrm{Ru}(\text { phen })_{2}(\mathrm{Cl})_{2}\right] \mathrm{Cl} \cdot 2 \mathrm{H}_{2} \mathrm{O}$ and $\left[\mathrm{Ru}(\mathrm{Phen})_{2}(\mathrm{G})(\mathrm{Cl})\right] \mathrm{Cl} \cdot 2 \mathrm{H}_{2} \mathrm{O}$. 
TABLE 2: Electronic spectral data of the salt and complexes.

\begin{tabular}{lcc}
\hline Complex & Band position $(\mathrm{nm})$ & Assignment \\
\hline $\mathrm{RuCl}_{3}$ & 295,573 & ${ }^{*} \mathrm{LMCT}, \mathrm{d}-\mathrm{d}\left({ }^{2} \mathrm{~T}_{2 \mathrm{~g}} \rightarrow{ }^{2} \mathrm{~T}_{1 \mathrm{~g}}\right)$ \\
{$\left[\mathrm{Ru}(\text { phen })_{2}(\mathrm{Cl})_{2}\right] \mathrm{Cl} \cdot 2 \mathrm{H}_{2} \mathrm{O}$} & 643 & $\mathrm{~d}-\mathrm{d}\left({ }^{2} \mathrm{~T}_{2 \mathrm{~g}} \rightarrow{ }^{2} \mathrm{~T}_{1 \mathrm{~g}}\right)$ \\
{$\left[\mathrm{Ru}(\text { phen })_{2}(\mathrm{G})(\mathrm{Cl})\right] \mathrm{Cl} \cdot \mathrm{H}_{2} \mathrm{O}$} & 657 & $\mathrm{~d}-\mathrm{d}\left({ }^{2} \mathrm{~T}_{2 \mathrm{~g}} \rightarrow{ }^{2} \mathrm{~T}_{1 \mathrm{~g}}\right)$ \\
\hline
\end{tabular}

${ }^{*}$ LMCT: ligand to metal charge transfer.

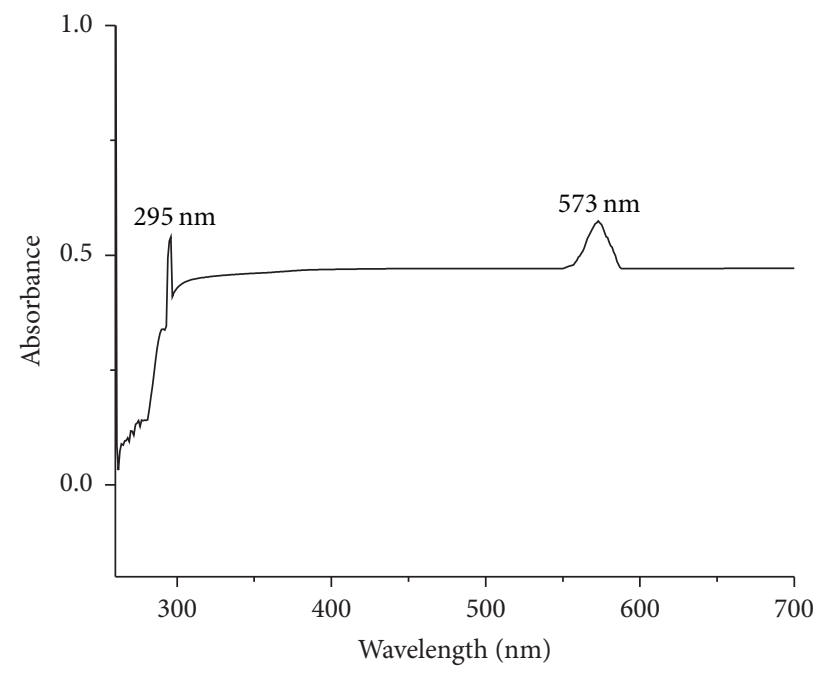

(a)

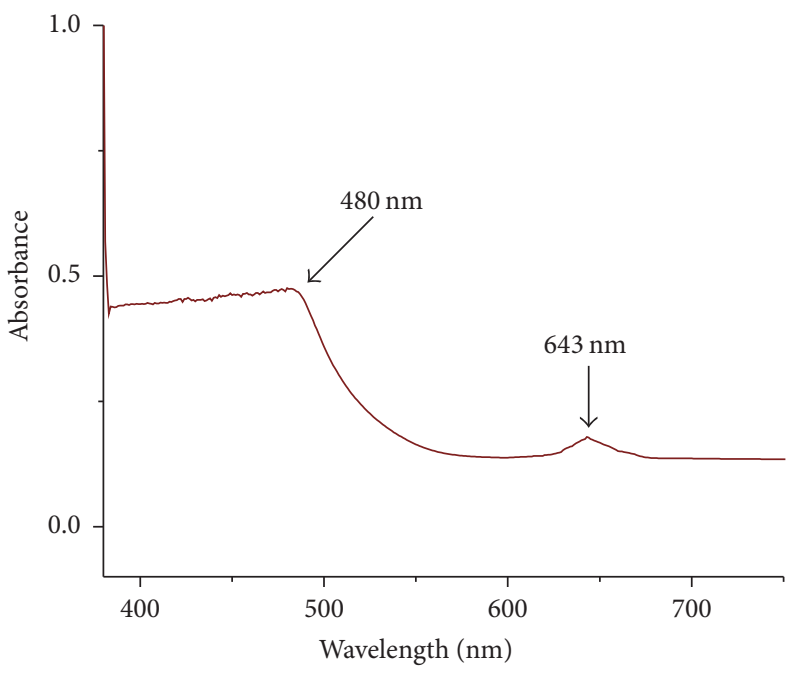

(b)

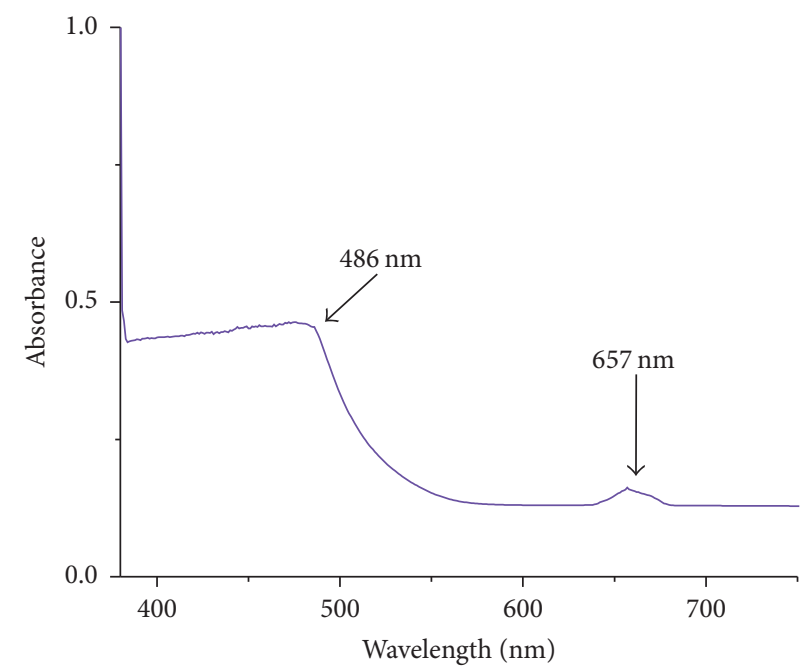

(c)

FIGURE 1: Electronic spectra of (a) $\mathrm{RuCl}_{3}$, (b) $\left[\mathrm{Ru}(\mathrm{phen})_{2} \mathrm{Cl}_{2}\right] \mathrm{Cl} \cdot 2 \mathrm{H}_{2} \mathrm{O}$, and (c) $\left[\mathrm{Ru}(\text { phen })_{2}(\mathrm{G}) \mathrm{Cl}\right] \mathrm{Cl} \cdot \mathrm{H}_{2} \mathrm{O}$.

because guanide $\left(\mathrm{G}^{-}\right)$formed a shorter and stronger bond that narrowed the transition $\left(\mathrm{t}_{2 \mathrm{~g}} \rightarrow e_{\mathrm{g}}\right.$ ) gap (Figure 1 and Table 2).

3.3. IR Spectroscopy. The infrared spectra of the ligands and the complexes are indicated in Figure 2 and selected characteristic frequencies are indicated in Table 3.

The bands at $1623 \mathrm{~cm}^{-1}(\mathrm{~s})$ and $1587 \mathrm{~cm}^{-1}(\mathrm{~s})$, characteristic for $v_{\mathrm{C}=\mathrm{C}}$ and $v_{\mathrm{C}=\mathrm{N}}$ stretching in the free 1,10-phenanthroline monohydrate (Figure 2(a)), appear at $1670 \mathrm{~cm}^{-1}(\mathrm{w})$ and
$1429 \mathrm{~cm}^{-1}(\mathrm{w})$, respectively, in $\left[\mathrm{Ru}(\text { phen })_{2}(\mathrm{G})(\mathrm{Cl})\right] \mathrm{Cl} \cdot \mathrm{H}_{2} \mathrm{O}$ (Figure 2(d)). They also appeared at $1633 \mathrm{~cm}^{-1}$ (w) and $1540 \mathrm{~cm}^{-1}(\mathrm{w})$, respectively, in $\left[\mathrm{Ru}(\text { phen })_{2}(\mathrm{Cl})_{2}\right] \mathrm{Cl} \cdot 2 \mathrm{H}_{2} \mathrm{O}$ (Figure 2(c)). Similarly, the characteristic bands of guanide at $3335 \mathrm{~cm}^{-1}$ (s), $3112 \mathrm{~cm}^{-1}$ (s) $\nu_{\mathrm{N}-\mathrm{H}}\left(\mathrm{NH}_{2}\right)$, and $1710 \mathrm{~cm}^{-1}$ (s) $\left(v_{\mathrm{C}=\mathrm{O}}\right)$ (Figure 2(b)) are displaced towards $3340 \mathrm{~cm}^{-1}(\mathrm{w})$ and $1697 \mathrm{~cm}^{-1}$ (w) (Figure 2(d)), respectively. The changes in absorption frequencies and strength suggest that 1,10-phenanthroline and guanide are coordinated. The strong and broad bands at $3439 \mathrm{~cm}^{-1}$ and $3416 \mathrm{~cm}^{-1}$ characteristic for 


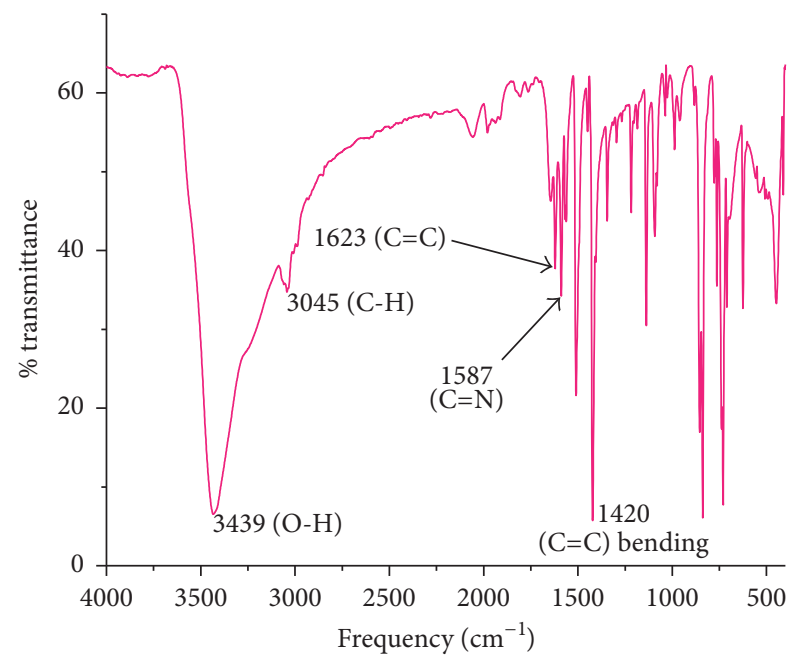

(a)

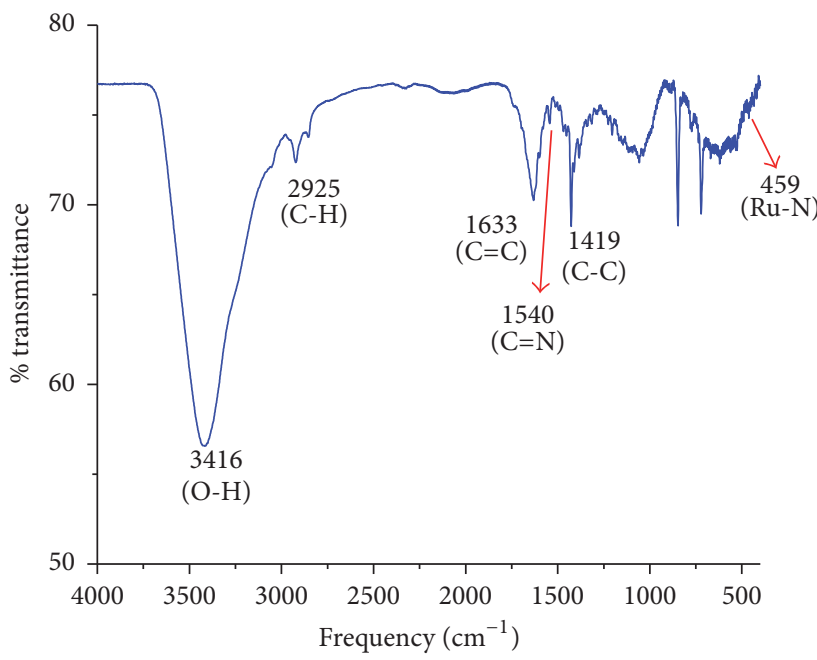

(c)

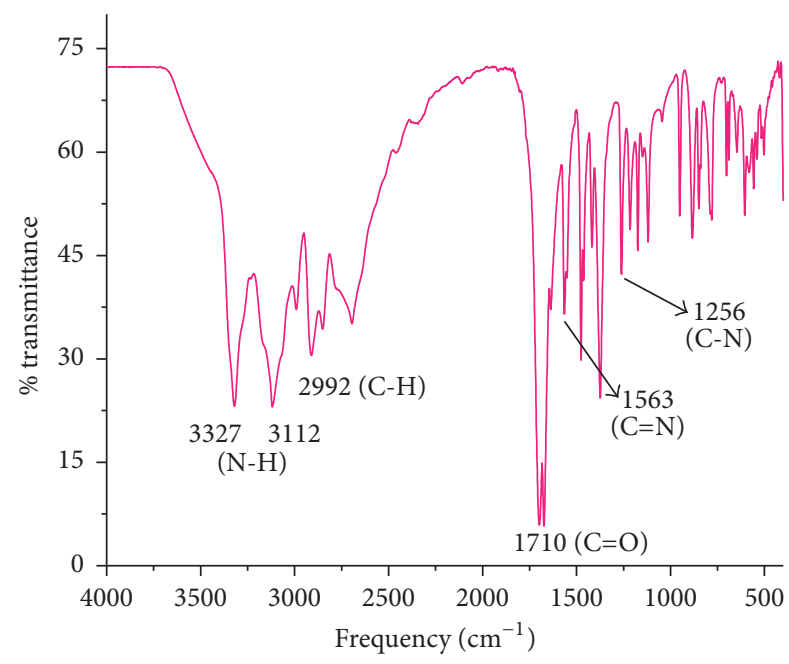

(b)

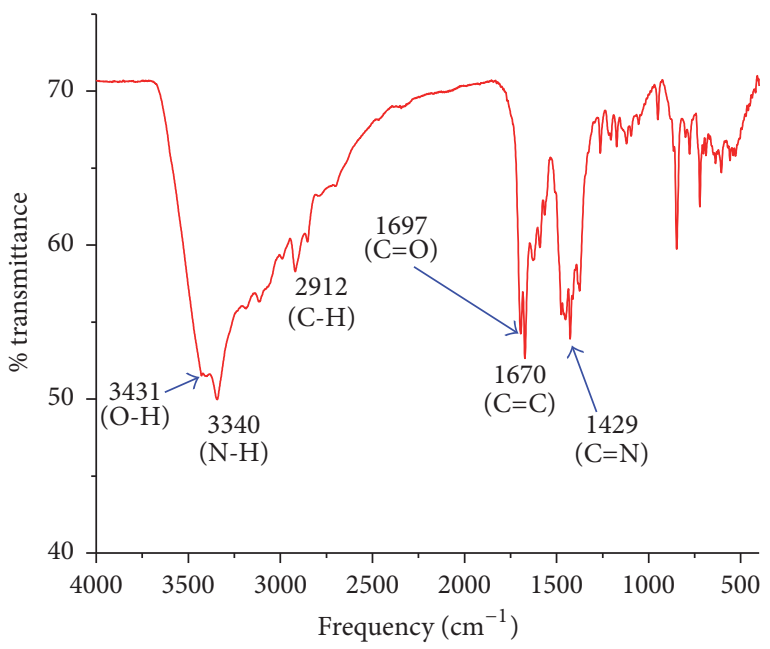

(d)

FIGURE 2: FTIR spectra of (a) 1,10-phenanthroline monohydrate, (b) guanine, (c) $\left[\mathrm{Ru}(\text { phen })_{2}(\mathrm{Cl})_{2}\right] \mathrm{Cl} \cdot 2 \mathrm{H}_{2} \mathrm{O}$, and $(\mathrm{d})\left[\mathrm{Ru}(\mathrm{phen})_{2}(\mathrm{G})(\mathrm{Cl})\right] \mathrm{Cl}$. $\mathrm{H}_{2} \mathrm{O}$.

TABLE 3: Important characteristic IR bands of the ligands and complexes, $\mathrm{cm}^{-1}$.

\begin{tabular}{|c|c|c|c|c|c|c|c|}
\hline \multirow{2}{*}{ Compound } & \multicolumn{7}{|c|}{ Absorption frequencies, $\mathrm{cm}^{-1}$} \\
\hline & $v(\mathrm{O}-\mathrm{H})$ & $v(\mathrm{~N}-\mathrm{H})$ & $v(\mathrm{C}-\mathrm{H})$ & $\nu(\mathrm{C}-\mathrm{N})$ & $\nu(\mathrm{C}=\mathrm{C})$ & $\nu(\mathrm{C}=\mathrm{N})$ & $v(\mathrm{C}=\mathrm{O})$ \\
\hline 1,10-Phenanthroline monohydrate & $3439(\mathrm{~s}, \mathrm{~b})$ & - & $3045(w)$ & $1290(\mathrm{w})$ & $1623(\mathrm{~s})$ & $1587(\mathrm{~s})$ & - \\
\hline Guanine & - & $3335,3112(d)$ & 2992 & $1256(\mathrm{w})$ & 1692 & $1563(w)$ & $1710(\mathrm{~s})$ \\
\hline$\left[\mathrm{Ru}(\mathrm{Phen})_{2}(\mathrm{Cl})_{2}\right] \mathrm{Cl} \cdot 2 \mathrm{H}_{2} \mathrm{O}$ & $3416(s, b)$ & - & $2925(\mathrm{w})$ & $1208(\mathrm{w})$ & $1633(\mathrm{w})$ & $1540(\mathrm{w})$ & - \\
\hline$\left[\mathrm{Ru}(\mathrm{Phen})_{2}(\mathrm{G})(\mathrm{Cl})\right] \mathrm{Cl} \cdot \mathrm{H}_{2} \mathrm{O}$ & 3431 & $3340(\mathrm{~s})$ & $2912(w)$ & 1270 & 1670 & 1429 & 1697 \\
\hline
\end{tabular}

s: strong, b: broad, w: weak, and d: doublet.

$v_{\mathrm{O}-\mathrm{H}}\left(\mathrm{H}_{2} \mathrm{O}\right)$ in the free 1,10-phenanthroline monohydrate and $\left[\mathrm{Ru}(\text { phen })_{2}(\mathrm{Cl})_{2}\right] \mathrm{Cl} \cdot 2 \mathrm{H}_{2} \mathrm{O}$, respectively (Figures $2(\mathrm{a})$ and 2(b)), appear at $3431 \mathrm{~cm}^{-1}$ obscured in the band characteristic for $\nu_{\mathrm{N}-\mathrm{H}}\left(\mathrm{NH}_{2}\right)$ in $\left[\mathrm{Ru}(\text { phen })_{2}(\mathrm{G})(\mathrm{Cl})\right] \mathrm{Cl} \cdot \mathrm{H}_{2} \mathrm{O}$ (Figure $2(\mathrm{~d})$ ). This change in the absorption frequency of water explains the change in the nature of its interaction. Moreover, the change in the intensity may explain the change in the relative amount of water molecules in 1,10-phenanthroline monohydrate and the complexes. The latter argument supports the proposed formula of the complexes.

3.4. Antibacterial Activity Testing. This observation shows that the complexes demonstrated biological activities against all the tested strains (Figure 3 and Table 4). The observed 


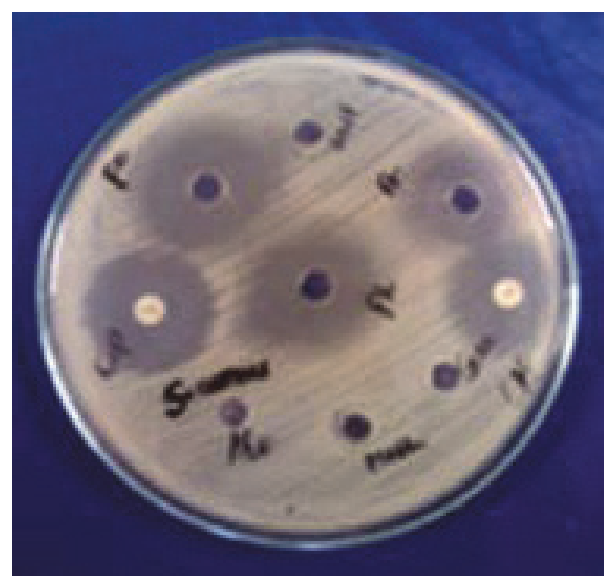

S. aureus

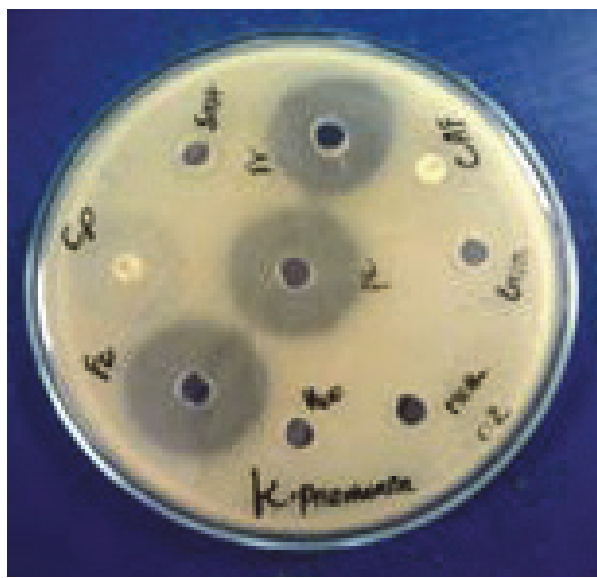

K. pneumoniae

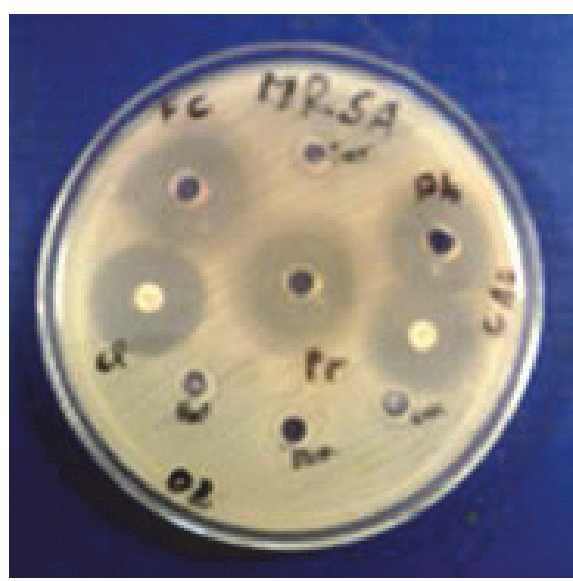

MRSA

(a)

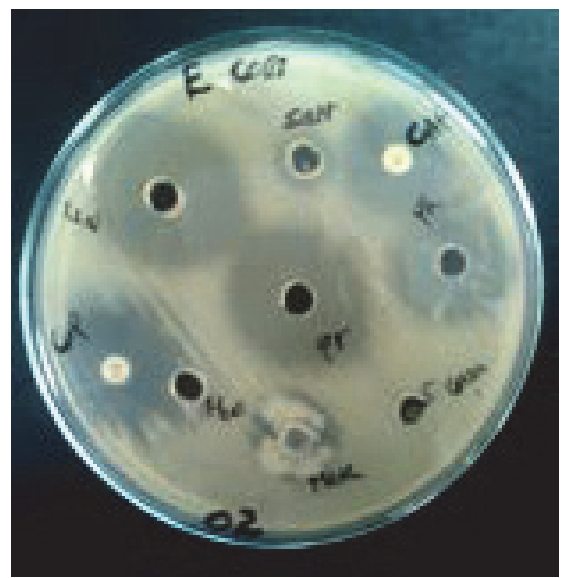

E. coli

(b)

FIGURE 3: Inhibition zone of ligands, complexes, salt, and commercial antibiotics against (a) Gram-positive (S. aureus and MARSA) and (b) Gram-negative (K. pneumoniae and E. coli) bacteria.

TABLE 4: Antibacterial activities of the complexes, free ligands, metal salt, and commercially available antibiotics.

\begin{tabular}{|c|c|c|c|c|}
\hline \multirow[b]{2}{*}{ Compound } & \multicolumn{4}{|c|}{ Inhibition zone (mm) } \\
\hline & $\begin{array}{c}\text { S. aureus } \\
\text { (ATCC 25923) }\end{array}$ & $\begin{array}{c}\text { MRSA } \\
\text { (clinical isolate) }\end{array}$ & $\begin{array}{c}\text { E. coli } \\
\text { (ATC 255922) }\end{array}$ & $\begin{array}{c}\text { K. pneumonia } \\
\text { (ATCC 986605) }\end{array}$ \\
\hline 1,10-Phenanthroline & $27.40 \pm 0.12$ & $26.4 \pm 0.11$ & $28.20 \pm 0.12$ & $26.00 \pm 0.14$ \\
\hline Guanine & - & - & - & - \\
\hline $\mathrm{RuCl}_{3}$ & - & - & $12.20 \pm 0.21$ & - \\
\hline$\left[\mathrm{Ru}(\mathrm{Phen})_{2}(\mathrm{Cl})_{2}\right] \mathrm{Cl} \cdot 2 \mathrm{H}_{2} \mathrm{O}$ & $25.54 \pm 0.15$ & $24.56 \pm 0.2$ & $26.53 \pm 0.13$ & $26.50 \pm 0.13$ \\
\hline$\left[\mathrm{Ru}(\text { Phen })_{2}(\mathrm{G})(\mathrm{Cl})\right] \mathrm{Cl} \cdot \mathrm{H}_{2} \mathrm{O}$ & $29.65 \pm 0.13$ & $28.8 \pm 0.21$ & $30.70 \pm 0.11$ & $30.70 \pm 0.11$ \\
\hline Ciprofloxacin & $28.00 \pm 0.14$ & $27.4 \pm 0.13$ & $30.00 \pm 0.10$ & $26.20 \pm 0.32$ \\
\hline Chloramphenicol & $25.24 \pm 0.14$ & $22.6 \pm 0.15$ & $26.50 \pm 0.23$ & $20.20 \pm 0.35$ \\
\hline
\end{tabular}

increase in antibacterial activity can be explained on the basis of Overtone's concept [36] and Tweedy's chelation theory [37]. The lipid membrane that surrounds the cell favors the passage of only lipid soluble materials which is an important condition for antimicrobial activity. On coordination, the polarity of the metal ion will be reduced to a greater extent due to the overlap of the ligand orbitals and partial sharing of the positive charge of the metal ion with the donor groups. Further, it increases the delocalization of $\pi$ electrons over the whole chelate ring and hence enhances the liposolubility 
TABle 5: The \% activity index data of the complexes against the tested bacteria compared to (a) Chloramphenicol and (b) Ciprofloxacin.

(a)

\begin{tabular}{|c|c|c|c|c|}
\hline \multicolumn{5}{|c|}{ Microorganism } \\
\hline Compound & S. aureus & MRSA & E. coli & K. pneumoniae \\
\hline$\left[\mathrm{Ru}(\text { Phen })_{2}(\mathrm{Cl})_{2}\right] \mathrm{Cl} \cdot \mathrm{H}_{2} \mathrm{O}$ & $11.00 \%$ & $8.70 \%$ & $0.10 \%$ & $31.20 \%$ \\
\hline$\left[\mathrm{Ru}(\mathrm{Phen})_{2}(\mathrm{G})(\mathrm{Cl})\right] \mathrm{Cl} \cdot \mathrm{H}_{2} \mathrm{O}$ & $17.50 \%$ & $27.40 \%$ & $15.85 \%$ & $52.00 \%$ \\
\hline
\end{tabular}

(b)

\begin{tabular}{lcccc}
\hline & & & \\
& Microorganism & E. coli & K. pneumoniae \\
Compound & S. aureus & MRSA & $-12.00 \%$ & $1.01 \%$ \\
{$\left[\mathrm{Ru}(\mathrm{Phen})_{2}(\mathrm{Cl})_{2}\right] \mathrm{Cl} \cdot 2 \mathrm{H}_{2} \mathrm{O}$} & $-8.80 \%$ & $-10.00 \%$ & $2.30 \%$ & $17.17 \%$ \\
{$\left[\mathrm{Ru}(\mathrm{Phen})_{2}(\mathrm{G})(\mathrm{Cl})\right] \mathrm{Cl} \cdot \mathrm{H}_{2} \mathrm{O}$} & $5.90 \%$ & $5.10 \%$ & & \\
\hline
\end{tabular}

MRSA: methicillin resistant $S$. aureus.

TABLE 6: MIC assay of $\left[\mathrm{Ru}(\mathrm{Phen})_{2}(\mathrm{G})(\mathrm{Cl})\right] \mathrm{Cl}_{2} \cdot \mathrm{H}_{2} \mathrm{O}$ against four bacterial pathogens.

\begin{tabular}{|c|c|c|c|c|c|c|c|}
\hline \multirow{2}{*}{ Microorganism } & \multicolumn{7}{|c|}{ Minimum concentration of microorganism growth } \\
\hline & $200 \mu \mathrm{g} / \mathrm{mL}$ & $300 \mu \mathrm{g} / \mathrm{mL}$ & $400 \mu \mathrm{g} / \mathrm{mL}$ & $500 \mu \mathrm{g} / \mathrm{mL}$ & $600 \mu \mathrm{g} / \mathrm{mL}$ & $800 \mu \mathrm{g} / \mathrm{mL}$ & $1000 \mu \mathrm{g} / \mathrm{mL}$ \\
\hline S. aureus & + & + & - & - & - & - & - \\
\hline MRSA & + & + & + & + & - & - & - \\
\hline K. pneumoniae & + & + & - & - & - & - & - \\
\hline E. coli & + & - & - & - & - & - & - \\
\hline
\end{tabular}

Note: +: bacteria growth and -: no bacteria growth.

of the complexes. This increased liposolubility enhances the penetration of the complexes into the lipid membrane and interferes in the normal activities of the bacteria [38].

The percent activity indexes of the complexes against the reference antibiotics demonstrated significant comparative inhibitions (Table 5). [ Ru(phen) $\left.)_{2}(\mathrm{G})(\mathrm{Cl})\right] \mathrm{Cl} \cdot \mathrm{H}_{2} \mathrm{O}$ showed better activity than the two commercial antibiotics (Ciprofloxacin and Chloramphenicol) against all the strains studied including the most drug resistant Gram-negative K. pneumoniae. $\left[\mathrm{Ru}(\mathrm{phen})_{2}(\mathrm{Cl})_{2}\right] \mathrm{Cl} \cdot 2 \mathrm{H}_{2} \mathrm{O}$ also showed nearly equal activities as Chloramphenicol against $S$. aureus and E. coli and better activities against MARSA and K. pneumoniae (Table 5). The better activities demonstrated by $\left[\mathrm{Ru}(\text { phen })_{2}(\mathrm{G})(\mathrm{Cl})\right] \mathrm{Cl}$. $\mathrm{H}_{2} \mathrm{O}$ compared to $\left[\mathrm{Ru}(\text { phen })_{2}(\mathrm{Cl})_{2}\right] \mathrm{Cl} \cdot 2 \mathrm{H}_{2} \mathrm{O}$ are due to its additional interaction with the genetic material of the cell by guanide.

3.5. Minimum Inhibitory Concentration (MIC) Determination. MIC is the lowest concentration that completely inhibited the growth of microorganisms for 24 hours.

Around $300 \mu \mathrm{g} / \mathrm{mL}\left[\mathrm{Ru}(\mathrm{Phen})_{2}(\mathrm{G})(\mathrm{Cl})\right] \mathrm{Cl} \cdot \mathrm{H}_{2} \mathrm{O}$ is sufficient to inhibit the growth of E. coli while around $400 \mu \mathrm{g} / \mathrm{mL}$ is necessary to start inhibiting $S$. aureus and $K$. pneumonia (Table 6).

\section{Conclusions}

In this synthesis, $\mathrm{Ru}(\mathrm{III})$ and the ligands are brought together with rigid configuration. This resulted in delocalization of $\pi$ electrons over the whole cationic unit and hence the reduction of the polarity of the complexes which increased the liposolubility. This has enhanced the penetration of the complexes into the lipid membrane and inhibited the growth of the tested Gram-positive and Gram-negative bacteria. The latter phenomenon demonstrates the wide-range activities of the complexes.

\section{Competing Interests}

There is no conflict of interests among the authors and the funding institution.

\section{Acknowledgments}

The authors express sincere thanks to Bahir Dar University for financial support.

\section{References}

[1] G. A. Lawrence, Introduction to Coordination Chemistry, John Wiley \& Sons, University of Newcastle, New South Wales, Australia, 2010.

[2] R. B. Sears, L. E. Joyce, and C. Turro, "Electronic tuning of ruthenium complexes by 8 -quinolate ligands," Photochemistry and Photobiology, vol. 86, no. 6, pp. 1230-1236, 2010.

[3] R. G. Wilkins, The Study of Kinetics and Mechanism of Reactions of Transition Metal Complexes, Allyn and Bacon, Boston, Mass, USA, 1974.

[4] J. L. Boyer, J. Rochford, M.-K. Tsai, J. T. Muckerman, and E. Fujita, "Ruthenium complexes with non-innocent ligands: electron distribution and implications for catalysis," Coordination Chemistry Reviews, vol. 254, no. 3-4, pp. 309-330, 2010. 
[5] Y. R. Goo, A. C. Maity, K.-B. Cho et al., "Tuning the reactivity of Chromium(III)-superoxo species by coordinating axial ligands," Inorganic Chemistry, vol. 54, no. 21, pp. 10513-10520, 2015.

[6] C. A. Tolman, "Steric effects of phosphorus ligands in organometallic chemistry and homogeneous catalysis," Chemical Reviews, vol. 77, no. 3, pp. 313-348, 1977.

[7] B. Mohapatra and S. Verma, "Crystal engineering with modified 2-aminopurine and group 12 metal ions," Crystal Growth \& Design, vol. 13, no. 7, pp. 2716-2721, 2013.

[8] D. K. Patel, A. Domínguez-Martín, M. del Pilar Brandi-Blanco, M. D. Choquesillo-Lazarte, V. M. Nurchi, and J. Niclós-Gutiérrez, "Metal ion binding modes of hypoxanthine and xanthine versus the versatile behaviour of adenine," Coordination Chemistry Reviews, vol. 256, no. 1-2, pp. 193-211, 2012.

[9] W. M. Motswainyana and P. A. Ajibade, "Anticancer activities of mononuclear ruthenium(II) coordination complexes," Advances in Chemistry, vol. 2015, Article ID 859730, 21 pages, 2015.

[10] S. Rafique, M. Idrees, A. Nasim, H. Akbar, and A. Athar, "Transition metal complexes as potential therapeutic agent," Biotechnology and Molecular Biology Reviews, vol. 5, no. 2, pp. 38-45, 2010.

[11] P. C. A. Bruijnincx and P. J. Sadler, "Controlling platinum, ruthenium, and osmium reactivity for anticancer drug design," Advances in Inorganic Chemistry, vol. 61, pp. 1-62, 2009.

[12] P. C. Bruijnincx and P. J. Sadler, "New trends for metal complexes with anticancer activity," Current Opinion in Chemical Biology, vol. 12, no. 2, pp. 197-206, 2008.

[13] K. Suntharalingam, T. C. Johnstone, P. M. Bruno, W. Lin, M. T. Hemann, and S. J. Lippard, "Bidentate ligands on osmium(VI) nitrido complexes control intracellular targeting and cell death pathways," Journal of the American Chemical Society, vol. 135, no. 38, pp. 14060-14063, 2013.

[14] M. Carreira, R. Calvo-Sanjuán, M. Sanaú, I. Marzo, and M. Contel, "Organometallic palladium complexes with a water-soluble iminophosphorane ligand as potential anticancer agents," Organometallics, vol. 31, no. 16, pp. 5772-5781, 2012.

[15] A. Mishra, H. Jung, J. W. Park et al., "Anticancer activity of selfassembled molecular rectangles via arene-ruthenium acceptors and a new unsymmetrical amide ligand," Organometallics, vol. 31, no. 9, pp. 3519-3526, 2012.

[16] L. Glans, A. Ehnbom, C. de Kock et al., "Ruthenium (II) arene complexes with chelating chloroquine analogue ligands: synthesis, characterization and in vitro antimalarial activity," Dalton Transactions, vol. 41, no. 9, pp. 2764-2773, 2012.

[17] L. Vela, M. Contel, L. Palomera, G. Azaceta, and I. Marzo, "Iminophosphorane-organogold(III) complexes induce cell death through mitochondrial ROS production," Journal of Inorganic Biochemistry, vol. 105, no. 10, pp. 1306-1313, 2011.

[18] C. S. Allardyce and P. J. Dyson, "Metal-based drugs that break the rules," Dalton Transactions, vol. 45, no. 8, pp. 3201-3209, 2016.

[19] F. Kratz and L. Messori, "Spectral characterization of ruthenium(III) transferrin," Journal of Inorganic Biochemistry, vol. 49, no. 2, pp. 79-82, 1993.

[20] S. H. van Rijt and P. J. Sadler, "Current applications and future potential for bioinorganic chemistry in the development of anticancer drugs," Drug Discovery Today, vol. 14, no. 23-24, pp. 1089-1097, 2009.
[21] J. C. R. Dabrowiak, “Titanium and gallium for cancer," in Metals in Medicine, pp. 149-189, John Wiley \& Sons, New York, NY, USA, 2009.

[22] E. Alessio, Bioinorganic Medicinal Chemistry, John Wiley \& Sons, New York, NY, USA, 2011.

[23] S. Page and R. Wheeler, "Ruthenium compounds as anticancer agents," Education in Chemistry, 2012, http://www.rsc.org/eic.

[24] J. Reedijk, "Metal-ligand exchange kinetics in platinum and ruthenium complexes: significance for effectiveness as anticancer drugs," Platinum Metals Review, vol. 52, no. 1, pp. 2-11, 2008.

[25] A. O. Adeloye and P. A. Ajibade, "Synthesis and characterization of a $\mathrm{Ru}(\mathrm{II})$ complex with functionalized phenanthroline ligands having single-double linked anthracenyl and 1-methoxy-1buten-3-yne moieties," Molecules, vol. 15, no. 11, pp. 7570-7581, 2010.

[26] I. Turel, A. Golobič, J. Kljun, P. Samastur, U. Batista, and K. Sepčić, "New synthetic routes for the preparation of ruthenium1,10-phenanthroline complexes. Tests of cytotoxic and antibacterial activity of selected ruthenium complexes," Acta chimica Slovenica, vol. 62, no. 2, pp. 337-345, 2015.

[27] P. Bonneson, J. L. Walsh, W. T. Pennington, A. W. Cordes, and B. Durham, "Six-coordinate complexes with 1,10-phenanthroline ligands in the trans configuration. Preparation of trans-bis(1,10phenanthroline)ruthenium(II) complexes and crystal structure of trans-bis(1,10-phenanthroline)bis(pyridine)ruthenium(II) hexafluorophosphate," Inorganic Chemistry, vol. 22, no. 12, pp. 1761-1765, 1983.

[28] F. Schaeffer, S. Rimsky, and A. Spassky, "DNA-stacking interactions determine the sequence specificity of the deoxyribonuclease activity of 1,10-phenanthroline-copper ion," Journal of Molecular Biology, vol. 260, no. 4, pp. 523-539, 1996.

[29] P. Lincoln and B. Nordén, "DNA binding geometries of ruthenium(II) complexes with 1,10-phenanthroline and 2,21bipyridine ligands studied with linear dichroism spectroscopy. Borderline cases of intercalation," The Journal of Physical Chemistry B, vol. 102, no. 47, pp. 9583-9594, 1998.

[30] J. E. Coury, J. R. Anderson, L. McFail-Isom, L. D. Williams, and L. A. Bottomley, "Scanning force microscopy of small ligandnucleic acid complexes: tris(o-phenanthroline)ruthenium(II) as a test for a new assay," Journal of the American Chemical Society, vol. 119, no. 16, pp. 3792-3796, 1997.

[31] A. M. Pyle, J. P. Rehmann, R. Meshoyrer, C. V. Kumar, N. J. Turro, and J. K. Barton, "Mixed-ligand complexes of ruthenium(II): factors governing binding to DNA," Journal of the American Chemical Society, vol. 111, no. 8, pp. 3051-3058, 1989.

[32] A. J. Bard, L. R. Faulkner, J. Leddy, and C. G. Zoski, Electrochemical Methods: Fundamentals and Applications, Wiley, New York, NY, USA, 1980.

[33] P. W. Atkins, Physical Chemistry, Oxfored University Press, Oxford, UK, 5th edition, 1994.

[34] C. E. Housecroft and A. G. Sharpe, Inorganic Chemistry, Pearson Education, England, UK, 2nd edition, 2005.

[35] G. L. Missler and D. A. Tarr, Inorganic Chemistry, Pearson Education, St. Olaf College, Northfield, Minn, USA, 3rd edition, 2004.

[36] N. Dharmaraj, P. Viswanathamurthi, and K. Natarajan, "Ruthenium(II) complexes containing bidentate Schiff bases and their antifungal activity," Transition Metal Chemistry, vol. 26, no. 1-2, pp. 105-109, 2001. 
[37] B. G. Tweedy, "Plant extracts with metal ions as potential antimicrobial agents," Phytopathology, vol. 55, pp. 910-914, 1964.

[38] P. V. Anantha Lakshmi, P. S. Reddy, and V. J. Raju, "Synthesis, characterization and antimicrobial activity of $3 \mathrm{~d}$ transition metal complexes of a biambidentate ligand containing quinoxaline moiety," Spectrochimica Acta Part A: Molecular and Biomolecular Spectroscopy, vol. 74, no. 1, pp. 52-57, 2009. 

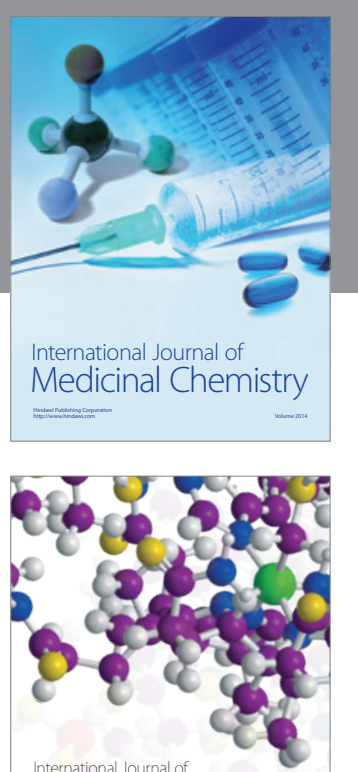

Carbohydrate Chemistry

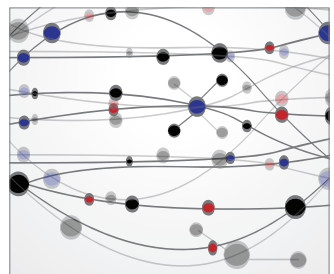

The Scientific World Journal
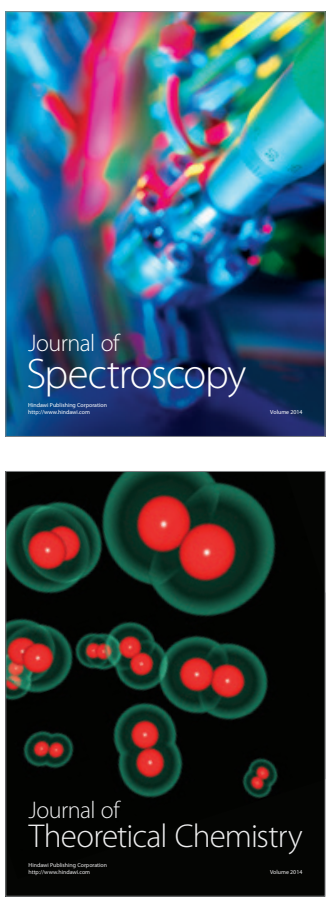
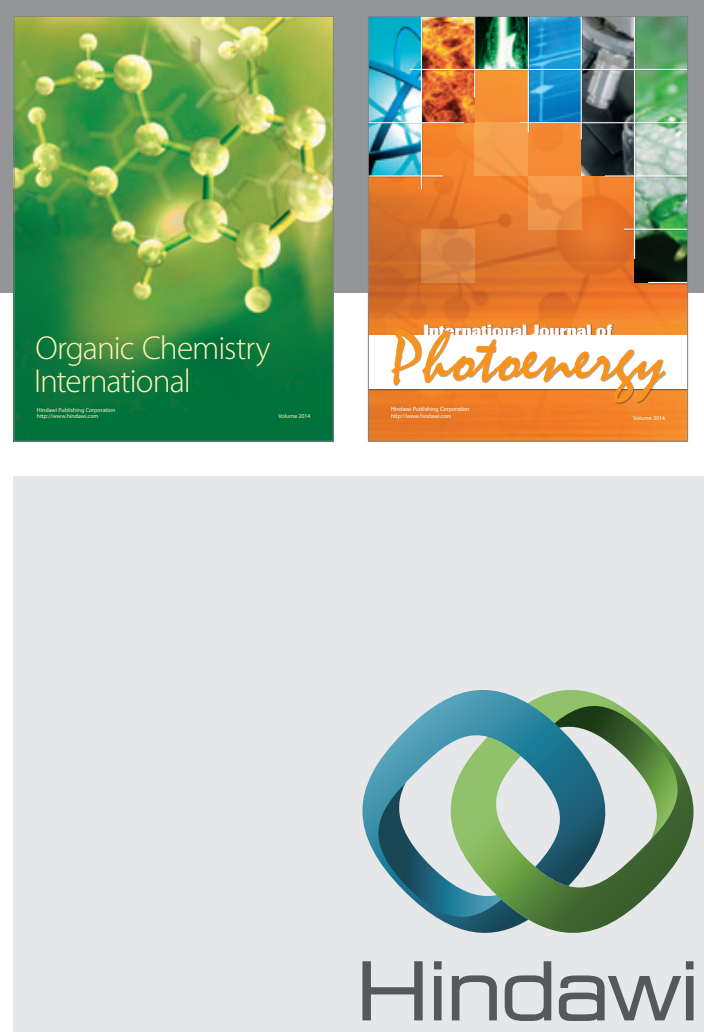

Submit your manuscripts at

http://www.hindawi.com

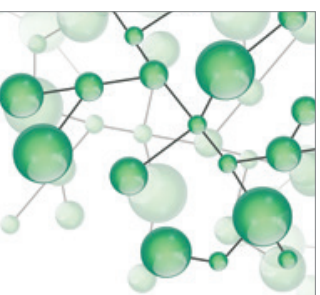

International Journal of

Inorganic Chemistry

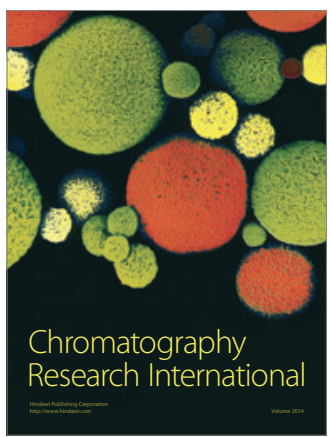

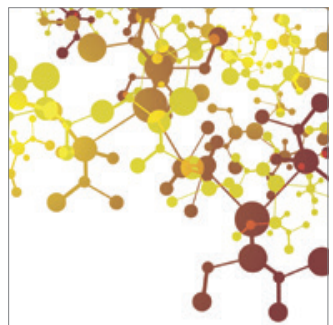

Applied Chemistry
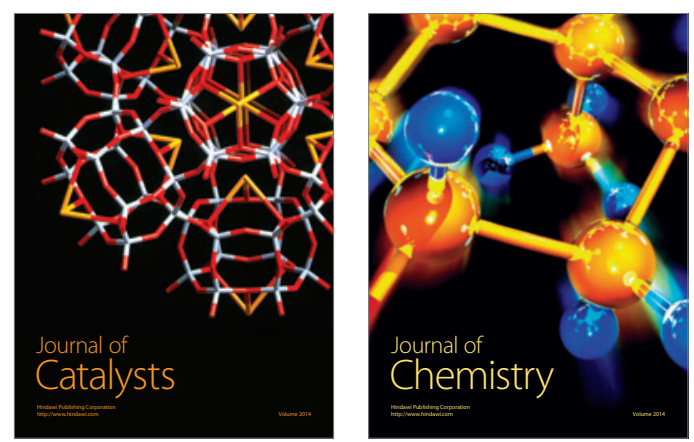
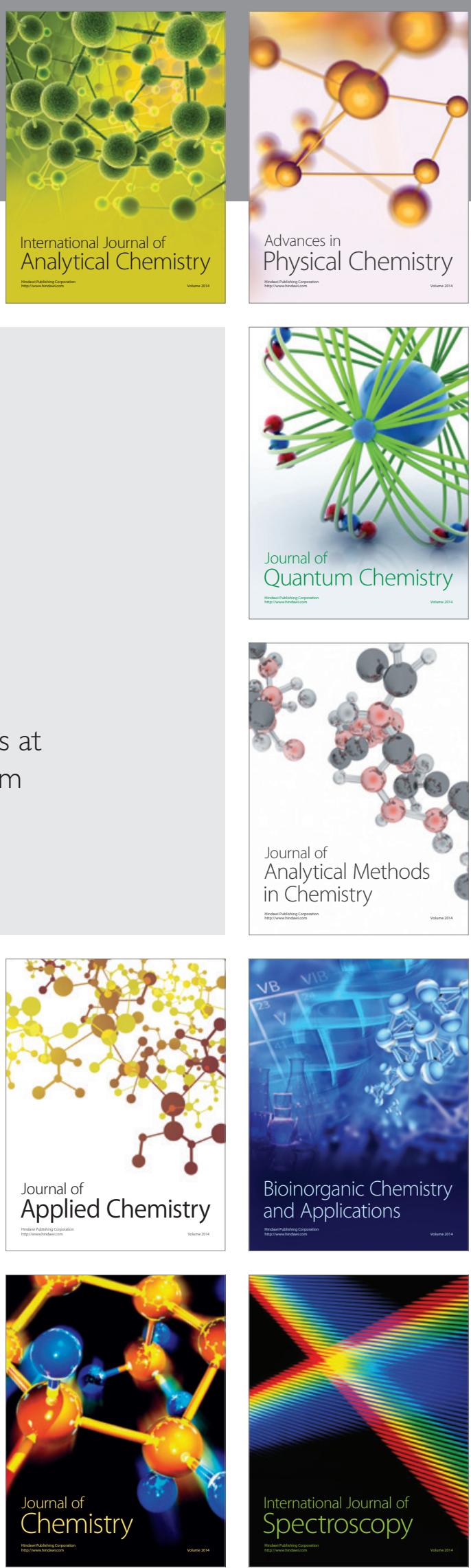